Proceedings of the 2018 International Scientific Conference 'Economic Sciences for Agribusiness and Rural Economy' No 2, Warsaw, 7-8 June 2018, pp. 216-222

\title{
TRANSFER OF EXTREME RISK BETWEEN SELECTED EU WHEAT MARKETS
}

\author{
Małgorzata Just, $\mathrm{PhD}^{1}$ \\ Faculty of Economics and Social Sciences, Poznań University of Life Sciences
}

\begin{abstract}
The aim of this study was to analyse the transfer of extreme price risk between selected EU milling wheat markets in the years 2005-2015. Extreme price risk (value at risk) was estimated using the ARMA-GARCH-EVT models. In turn, the risk transfer phenomenon was identified using the Granger causality in risk test according to Cheung and $\mathrm{Ng}$, the Granger test in relation to logarithmic price increments exceeding values at risk and the quotient of these increments and values at risk. Results of these tests indicate the effect of extreme price risk transfer on the EU milling wheat markets in the years 2005-2015. The market from which the risk was most frequently transferred was the wheat market in France, while the wheat markets in Poland and in Germany were those, onto which the risk was most frequently transferred.
\end{abstract}

Keywords: spillover effect, Granger causality in risk, value at risk, wheat prices

JEL codes: C58, Q11

\section{INTRODUCTION}

The market for milling wheat is a major agricultural produce market in the European Union. The leading EU wheat producers include France, Germany, Great Britain and Poland. In turn, the key futures market (characterised by the greatest liquidity) for wheat in Europe is the futures market for futures contracts listed on the Euronext exchange in Paris. For the entities on the agricultural market it is essential to determine the mechanism transmitting the price risk between wheat markets due to high fluctuations in wheat prices, since extreme price variations constitute the greatest threat and chance for business entities. Extreme price risk refers to events characterised by low probability of occurrence and high losses incurred when they take place (Jajuga, 2007). These events on the markets are caused by the release of surprising information, economic crises, natural disasters and spillover from other markets (Faldziński, 2014). Results of empirical studies indicate that wheat markets within the EU are interrelated (Rembeza, 2009; Hamulczuk and Łopaciuk, 2013; Hamulczuk, 2015). For this reason we may observe transfer of the extreme price risk between wheat markets within the EU. Studies conducted to date have analysed primarily causality between cash prices for wheat and cash and futures prices for wheat in Europe and the USA. Thus the aim of this study was to supplement research to include the analysis of extreme price risk transfer between selected milling wheat markets in the European Union.

${ }^{1}$ Corresponding author: Wojska Polskiego 28, 60-637 Poznań, Poland, m.just@up.poznan.pl, +4861 8466214 


\section{MATERIALS AND METHODS}

This study used time series for average weekly milling wheat prices from selected EU countries (Integrated Agricultural Market Information System) and closing quotes for futures contracts for milling wheat from the Euronext exchange in Paris in the period from 3 January 2005 to 6 December 2015. All prices were synchronised, supplementing missing data with arithmetic means from the preceding and successive prices in relation to the missing price. The countries for analyses (France, Germany, Poland) were selected based on the volume of wheat production and availability of data on prices. Analyses were conducted on weekly percentage logarithmic increments of prices, which were established from the formula $r_{t}=100 \ln \left(P_{t} / P_{t-1}\right)$, where $P_{t}$ denotes an average weekly price of wheat in time $t$. Considering the properties of logarithmic wheat price increments (the occurrence of autocorrelation and the effect of $\mathrm{ARCH}$, leptokurtosis and skeweness of distributions), the extreme price risk (values at risk) on the wheat markets were determined using the peaks over threshold approach with volatility models (ARMAGARCH-EVT models). In turn, in order to detect the phenomenon of risk transfer the Granger test for causality in risk according to Cheung and $\mathrm{Ng}$ was used. In order to confirm the results of this test additionally the Granger test was applied in relation to extreme logarithmic price increments and the quotient of these increments and values at risk. The effect of lags of one and two weeks were investigated.

In order to apply causality tests we need to determine values at risk. Let $X_{t}$ and $Y_{t}$ denote stationary stochastic processes with discrete time and let $F_{X Y, t-1}=\left\{X_{t-j}, Y_{t-j}, j=1,2, \ldots\right\} \quad$ be a set of information available in time $t-1$, and $F_{Y, t-1}=\left\{Y_{t-j}, j=1,2, \ldots\right\}$ will be a set of the same information excluding information on process $X_{t}$. The term value at risk $(\mathrm{VaR})$ denotes the percentage loss in commodity value. Formally the value at risk at the level of tolerance $\alpha$ for the long (short) position in a commodity is a number opposite to the quantile of order $\alpha$ (quantile of order $1-\alpha$ ) for the conditional distribution $Y_{t}$ (Doman and Doman, 2009): $P\left(Y_{t} \leq-\operatorname{VaR}_{Y_{t}}(\alpha) \mid F_{Y, t-1}\right)=\alpha$, $\left(P\left(Y_{t} \geq \operatorname{VaR}_{Y_{t}}(1-\alpha) \mid F_{Y, t-1}\right)=\alpha\right)$. This paper investigated percentage logarithmic increments in wheat prices $r_{t}$. It was assumed that $r_{t}$ are generated by the process (Doman and Doman, 2009) $r_{t}=\mu_{t}+\sigma_{t} \varepsilon_{t}$, where: $\mu_{t}=E\left(r_{t} \mid F_{r, t-1}\right), \sigma_{t}^{2}=\operatorname{var}\left(r_{t} \mid F_{r, t-1}\right)$, $\varepsilon_{t} \sim \operatorname{iid}(0,1)$. Thus VaR were expressed for the long and short positions using the respective formula:

$$
\begin{aligned}
& \operatorname{VaR}_{r_{t+1}}(\alpha)=-\mu_{t}(1)-\sigma_{t}(1) F_{\varepsilon_{t}}^{-1}(\alpha), \\
& \operatorname{VaR}_{r_{t+1}}(1-\alpha)=\mu_{t}(1)+\sigma_{t}(1) F_{\varepsilon_{t}}^{-1}(1-\alpha),
\end{aligned}
$$

where:

$\mu_{t}(1), \sigma_{t}(1)$ - forecasts for one period ahead, respectively, for the conditional mean and conditional standard deviation;

$F_{\varepsilon_{t}}^{-1}(\alpha), F_{\varepsilon_{t}}^{-1}(1-\alpha)$ - quantile $\varepsilon_{t}$ of order $\alpha$ and $1-\alpha$, respectively.

In this study respective ARMA models were fit to the conditional mean and GARCH models with Student's $t$-distribution or skewed Student's $t$-distribution for conditional standard deviation. The ARMA and GARCH models are described e.g. in Doman and Doman (2009). Next the peaks over threshold model was used to model distribution tails for standardised residuals from the GARCH model (assuming 12.5\% observations to be extreme observations). This made it possible to model only distribution tails instead of entire distributions, i.e. more accurate estimation of distribution tails. A detailed description of this method (GARCH-EVT models) is presented in (McNeil and Frey, 2000). Values at risk were determined for the long and short positions in wheat (the left and right distribution tails for wheat price increments) for the level of tolerance of 0.1 .

The Granger test was conducted based on the determined values at risk. In the causality concept introduced by Granger (1969) it is assumed that $X_{t}$ is the Granger causality for $Y_{t}$, if current values $Y_{t}$ may be estimated more accurately using past values $X_{t}$ than without them (at the unchanged remainder informa- 
tion) (Osińska, 2006). In the Granger test a null hypothesis is verified, in which it is assumed that $X_{t}$ is not the Granger cause for $Y_{t}$ in the following form (Osińska, 2006): $\sigma^{2}\left(Y_{t} \mid F_{X Y, t-1}\right)<\sigma^{2}\left(Y_{t} \mid F_{Y, t-1}\right)$, where $\sigma^{2}$ denotes variance of the prediction error. If inequality is not satisfied, $X_{t}$ is the Granger cause for $Y_{t}$. Two models are estimated in this test:

$$
\begin{gathered}
Y_{t}=\alpha_{0}+\sum_{j=1}^{k} \alpha_{j} Y_{t-j}+\sum_{j=1}^{k} \beta_{j} X_{t-j}+\eta_{t}, \\
Y_{t}=\alpha_{0}+\sum_{j=1}^{k} \alpha_{j} Y_{t-j}+\varepsilon_{t},
\end{gathered}
$$

where:

$$
\begin{array}{ll}
\alpha_{0}, \alpha_{j}, \beta_{j} & - \text { parameters of the model; } \\
\eta_{t}, \varepsilon_{t} & - \text { random components; } \\
k & - \text { order of lag. }
\end{array}
$$

The next stage consists in the verification of the null hypothesis that all coefficients $\beta_{j}$ are equal to zero, which corresponds to the hypothesis on a lack of Granger causality. In this study linear regression models were estimated for extreme logarithmic wheat price increments on a given market. The price increments exceeding values at risk $\left(Y_{t} \leq-\operatorname{VaR}_{Y_{t}}(\alpha), Y_{t} \geq \operatorname{VaR}_{Y_{t}}(1-\alpha)\right)$ were considered extreme logarithmic price increments, while the other observations were ascribed the zero value. The test variant with the Fisher-Snedecor statistic was applied (Osińska, 2006):

$$
F=\frac{\left(S^{2}\left(\varepsilon_{t}\right)-S^{2}\left(\eta_{t}\right)\right) / k}{S^{2}\left(\eta_{t}\right) /(T-2 k-1)},
$$

where:

$S^{2}\left(\eta_{t}\right), S^{2}\left(\varepsilon_{t}\right)$ - square sum of residuals for the models presented in equation (2);

$T$-sample size.

At the correctness of the null hypothesis the $F$ statistic has the Fisher-Snedecor distribution with $k$ and $T-2 k-1$ degrees of freedom.

In the next stage of the study the Granger causality in risk test was conducted. The concept was introduced by Hong, Liu and Wang (2009). The occurrence of the Granger causality in risk means that the presence of high risk on one market makes it possible to more accurately estimate the occurrence of a similar risk on another market. This paper verifies the null hypothesis that $X_{t}$ is not the Granger cause in risk for $Y_{t}$ of the form (Hong, Liu and Wang, 2009):

$$
E\left(I_{Y, t} \mid F_{Y, t-1}\right)=E\left(I_{Y, t} \mid F_{X Y, t-1}\right) \text {, }
$$

where $I_{Y, t}$ denotes the indicator function, which for the long or short positions in the commodity assumes the value of one, respectively, when the logarithmic price increments exceed values at risk, while otherwise it takes the value of zero. When equation (4) is not met $X_{t}$ is the Granger cause in risk for $Y_{t}$. This study was conducted using the Granger causality in risk test according to Cheung and $\mathrm{Ng}$ (1996):

$$
C H N=T \sum_{j=1}^{k} r^{2}(j),
$$

where:

$T \quad$ - sample size;

$r(j)$ - estimator of the coefficient of cross-correlation $\rho(j)$ between $I_{X, t}$ and $I_{Y, t}$;

$k \quad-$ the order of delay.

The $C H N$ statistic for the correct null hypothesis takes the distribution convergent to $\chi^{2}(k)$.

\section{RESULTS AND DISCUSSION}

It is generally accepted that the method to determine values at risk provides good estimations when the number of exceedances of the estimated value at risk by empirical logarithmic price increments is consistent with the assumed level and the distribution of exceedances is uniform. The quality of estimations for the value at risk for logarithmic wheat price increments for the level of tolerance equal to 0.1 was evaluated using the Kupiec test (Kupiec, 1995), Christoffersen test (Christoffersen, 1998), Christoffersen and Pelletier test (Christoffersen and Pelletier, 2004). Results of these tests are presented in Table 1. Taking into consideration the results of the three tests it may be stated that all the estimations of values at risk were of good quality. The share of exceedances was close to the assumed level and the exceedances were uniformly distributed. 
Table 1. The evaluation of the VaR estimation quality

\begin{tabular}{|c|c|c|c|c|c|c|c|c|}
\hline \multirow{2}{*}{ Item } & \multicolumn{2}{|c|}{ Germany } & \multicolumn{2}{c|}{ France } & \multicolumn{2}{c|}{ Poland } & \multicolumn{2}{c|}{ Euronext in Paris } \\
\cline { 2 - 9 } & Left tail & Right tail & Left tail & Right tail & Left tail & Right tail & Left tail & Right tail \\
\hline ET & 57 & 57 & 57 & 57 & 57 & 57 & 57 & 57 \\
\hline $\mathrm{T}_{1}$ & 52 & 56 & 62 & 56 & 58 & 60 & 61 & 63 \\
\hline LR_UC & 0.481 & 0.016 & 0.495 & 0.016 & 0.023 & 0.185 & 0.321 & 0.705 \\
\hline p-value & 0.488 & 0.900 & 0.482 & 0.900 & 0.878 & 0.667 & 0.571 & 0.401 \\
\hline LR_CC & 2.742 & 0.066 & 0.579 & 0.473 & 0.305 & 2.805 & 3.617 & 0.884 \\
\hline p-value & 0.254 & 0.968 & 0.749 & 0.789 & 0.858 & 0.246 & 0.164 & 0.643 \\
\hline LR_D & 0.423 & 0.102 & 0.829 & 0.457 & 0.083 & 3.836 & 0.023 & 1.500 \\
\hline p-value & 0.516 & 0.750 & 0.363 & 0.499 & 0.773 & 0.050 & 0.879 & 0.221 \\
\hline
\end{tabular}

ET $\left(\mathrm{T}_{1}\right)$ - the expected (empirical) number of exceedances of the estimated VaR by the actual logarithmic prices increments; LR_UC (LR_CC, LR_D) - Kupiec (Christoffersen, Christoffersen and Pelletier) test statistic; in bold grey font - rejection of the null hypothesis Kupiec test: the share of VaR violations by actual logarithmic prices increments is compliant with an assumed $\alpha$ (Christoffersen test: the share of VaR hits by actual logarithmic prices increments is compliant with an assumed $\alpha$ and the exceedances are independent - the first hit; Christoffersen and Pelletier test: the duration of time (in weeks) between the violations of VaR by actual logarithmic prices increments is independent) for the significance level of 0.1 .

Source: own study.

Table 2 presents results of the Cheung and $\mathrm{Ng}$ test for the wheat long and short positions for delays of one and two weeks, respectively. Irrespective of the position occupied on the wheat market, the hypothesis on a lack of the Granger causality in risk for lags of one and two weeks for the pairs of wheat in France-wheat in Germany; wheat in France-wheat futures at the Euronext exchange; wheat futures at the Euronext exchange-wheat in Germany was rejected (at the level of significance of 0.05). In view of the fact that the analysed test ascribes identical weights to all the delays we need to state that significant correlation coefficients are indicated by considerable fluctuations in the test statistic. This means that the extreme price risk was transferred from the wheat market in France to the wheat market in Germany for lags amounting to one and two weeks, while it was transferred to the market of futures listed at the Euronext exchange only for the 1-week lag. The wheat market in Germany was the recipient of risk from the wheat futures market in Paris for lags of one and two weeks. Moreover, it was found that the wheat market in Poland was the recipient of risk from the wheat market in Germany in the case of extreme price hikes and from the wheat market in France in the case of extreme price drops for the 1-week lags.

Results of the Granger test conducted for the extreme logarithmic wheat price increments and the quotient of these increments and values at risk are presented in Table 3. Results of these tests confirmed the existence of the Granger causality in relation to extreme price reductions and hikes for the following pairs: wheat in France-wheat in Germany; wheat in France-wheat futures on the Euronext exchange; wheat futures on the Euronext exchange-wheat in Germany; wheat in Germany-wheat in Poland in the case of extreme price hikes. Additional tests indicated that extreme wheat price hikes on the cash and futures markets in France and extreme price reductions for wheat in Germany may have been the Granger causality for extreme hikes and reductions in wheat prices in Poland.

Generally it may be observed that the transmission of risk on the wheat market in Poland was observed more often in the case of short positions. In view of the fact that average wheat wholesale prices for wheat 
Proceedings of the 2018 International Scientific Conference 'Economic Sciences for Agribusiness and Rural Economy' No 2, Warsaw, 7-8 June 2018, pp. 216-222

Table 2. Results of the Cheung and $\mathrm{Ng}$ test

\begin{tabular}{|c|c|c|c|c|c|}
\hline \multirow{2}{*}{ Item } & \multirow{2}{*}{ Lag } & \multicolumn{2}{|c|}{ Left tail } & \multicolumn{2}{|c|}{ Right tail } \\
\hline & & 1 & 2 & 1 & 2 \\
\hline \multirow{2}{*}{$\sim \mathrm{F}->\mathrm{G}$} & $\mathrm{CHN}$ & 29.890 & 36.736 & 34.773 & 39.235 \\
\hline & p-value & 0.000 & 0.000 & 0.000 & 0.000 \\
\hline \multirow{2}{*}{$\sim \mathrm{G}->\mathrm{F}$} & $\mathrm{CHN}$ & 0.382 & 1.550 & 1.419 & 1.482 \\
\hline & p-value & 0.536 & 0.461 & 0.234 & 0.477 \\
\hline \multirow{2}{*}{$\sim \mathrm{F}->\mathrm{P}$} & $\mathrm{CHN}$ & 6.683 & 6.799 & 0.913 & 1.817 \\
\hline & p-value & 0.010 & 0.033 & 0.339 & 0.403 \\
\hline \multirow{2}{*}{$\sim \mathrm{P}->\mathrm{F}$} & $\mathrm{CHN}$ & 0.010 & 1.549 & 1.786 & 1.787 \\
\hline & p-value & 0.921 & 0.461 & 0.181 & 0.409 \\
\hline \multirow{2}{*}{$\sim \mathrm{F}->\mathrm{E}$} & $\mathrm{CHN}$ & 51.929 & 52.326 & 63.681 & 63.691 \\
\hline & p-value & 0.000 & 0.000 & 0.000 & 0.000 \\
\hline \multirow{2}{*}{$\sim \mathrm{E}->\mathrm{F}$} & $\mathrm{CHN}$ & 0.520 & 2.619 & 0.125 & 0.135 \\
\hline & p-value & 0.471 & 0.270 & 0.723 & 0.935 \\
\hline \multirow{2}{*}{$\sim \mathrm{G}->\mathrm{P}$} & $\mathrm{CHN}$ & 1.674 & 1.781 & 7.777 & 7.778 \\
\hline & p-value & 0.196 & 0.410 & 0.005 & 0.020 \\
\hline \multirow{2}{*}{$\sim \mathrm{P}->\mathrm{G}$} & $\mathrm{CHN}$ & 0.186 & 5.864 & 1.999 & 2.000 \\
\hline & p-value & 0.666 & 0.053 & 0.157 & 0.368 \\
\hline \multirow{2}{*}{$\sim \mathrm{G}->\mathrm{E}$} & $\mathrm{CHN}$ & 1.291 & 1.728 & 0.009 & 0.131 \\
\hline & p-value & 0.256 & 0.421 & 0.924 & 0.937 \\
\hline \multirow{2}{*}{$\sim \mathrm{E}->\mathrm{G}$} & $\mathrm{CHN}$ & 9.578 & 12.358 & 23.424 & 26.297 \\
\hline & p-value & 0.002 & 0.002 & 0.000 & 0.000 \\
\hline \multirow{2}{*}{$\sim \mathrm{P}->\mathrm{E}$} & $\mathrm{CHN}$ & 1.689 & 1.692 & 1.041 & 2.072 \\
\hline & p-value & 0.194 & 0.429 & 0.308 & 0.355 \\
\hline \multirow{2}{*}{$\sim \mathrm{E}->\mathrm{P}$} & $\mathrm{CHN}$ & 1.541 & 1.552 & 2.118 & 2.644 \\
\hline & p-value & 0.214 & 0.460 & 0.146 & 0.267 \\
\hline
\end{tabular}

F (G, P, E) - logarithmic increases in prices of wheat in France (in Germany, in Poland, contracts on the Euronext exchange); in bold black (grey) font - rejection of the null hypothesis on the lack of Granger causality in risk for the significance level of 0.05 $(0.1)$.

Source: own study. 
Proceedings of the 2018 International Scientific Conference 'Economic Sciences for Agribusiness and Rural Economy' No 2, Warsaw, 7-8 June 2018, pp. 216-222

Table 3. Results of the Granger test

\begin{tabular}{|c|c|c|c|c|c|c|c|c|c|}
\hline \multirow{3}{*}{ Item } & \multirow{3}{*}{ Lag } & \multicolumn{4}{|c|}{ Variant with extreme prices increments } & \multicolumn{4}{|c|}{$\begin{array}{c}\text { Variant with the quotient of extreme prices } \\
\text { increments and VaR }\end{array}$} \\
\hline & & \multicolumn{2}{|c|}{ Left tail } & \multicolumn{2}{|c|}{ Right tail } & \multicolumn{2}{|c|}{ Left tail } & \multicolumn{2}{|c|}{ Right tail } \\
\hline & & 1 & 2 & 1 & 2 & 1 & 2 & 1 & 2 \\
\hline \multirow{2}{*}{$\sim \mathrm{F}->\mathrm{G}$} & $\mathrm{F}$ & 36.282 & 22.979 & 29.160 & 20.554 & 35.290 & 21.138 & 20.616 & 20.110 \\
\hline & p-value & 0.000 & 0.000 & 0.000 & 0.000 & 0.000 & 0.000 & 0.000 & 0.000 \\
\hline \multirow{2}{*}{$\sim \mathrm{G}->\mathrm{F}$} & $\mathrm{F}$ & 0.875 & 0.911 & 1.409 & 2.118 & 0.571 & 1.104 & 1.189 & 0.405 \\
\hline & p-value & 0.350 & 0.403 & 0.236 & 0.121 & 0.450 & 0.332 & 0.276 & 0.667 \\
\hline \multirow{2}{*}{$\sim \mathrm{F}->\mathrm{P}$} & $\mathrm{F}$ & 1.075 & 0.537 & 6.374 & 5.460 & 3.336 & 1.907 & 1.745 & 6.885 \\
\hline & p-value & 0.300 & 0.585 & 0.012 & 0.004 & 0.068 & 0.149 & 0.187 & 0.001 \\
\hline \multirow{2}{*}{$\sim \mathrm{P}->\mathrm{F}$} & $\mathrm{F}$ & 0.160 & 0.075 & 0.513 & 0.380 & 0.027 & 0.081 & 1.651 & 0.772 \\
\hline & p-value & 0.689 & 0.928 & 0.474 & 0.684 & 0.869 & 0.923 & 0.199 & 0.463 \\
\hline \multirow{2}{*}{$\sim \mathrm{F}->\mathrm{E}$} & $\mathrm{F}$ & 98.306 & 48.873 & 264.331 & 132.933 & 63.031 & 31.348 & 140.400 & 70.175 \\
\hline & p-value & 0.000 & 0.000 & 0.000 & 0.000 & 0.000 & 0.000 & 0.000 & 0.000 \\
\hline \multirow{2}{*}{$\sim \mathrm{E}->\mathrm{F}$} & $\mathrm{F}$ & 0.873 & 1.783 & 1.594 & 2.952 & 0.010 & 1.079 & 0.150 & 0.126 \\
\hline & p-value & 0.351 & 0.169 & 0.207 & 0.053 & 0.922 & 0.341 & 0.699 & 0.882 \\
\hline \multirow{2}{*}{$\sim \mathrm{G}->\mathrm{P}$} & $\mathrm{F}$ & 2.597 & 6.984 & 20.992 & 10.133 & 0.688 & 7.724 & 13.374 & 6.782 \\
\hline & $\mathrm{p}$-value & 0.108 & 0.001 & 0.000 & 0.000 & 0.407 & 0.000 & 0.000 & 0.001 \\
\hline \multirow{2}{*}{$\sim \mathrm{P}->\mathrm{G}$} & $\mathrm{F}$ & 0.207 & 1.054 & 2.706 & 2.815 & 0.013 & 0.917 & 0.462 & 1.027 \\
\hline & p-value & 0.649 & 0.349 & 0.101 & 0.061 & 0.908 & 0.400 & 0.497 & 0.359 \\
\hline \multirow{2}{*}{$\sim \mathrm{G}->\mathrm{E}$} & $\mathrm{F}$ & 1.889 & 1.027 & 6.273 & 3.863 & 0.891 & 0.488 & 1.305 & 0.835 \\
\hline & p-value & 0.170 & 0.359 & 0.013 & 0.022 & 0.346 & 0.614 & 0.254 & 0.435 \\
\hline \multirow{2}{*}{$\sim \mathrm{E}->\mathrm{G}$} & $\mathrm{F}$ & 3.329 & 4.137 & 30.100 & 15.083 & 6.025 & 4.767 & 26.986 & 14.518 \\
\hline & p-value & 0.069 & 0.016 & 0.000 & 0.000 & 0.014 & 0.009 & 0.000 & 0.000 \\
\hline \multirow{2}{*}{$\sim \mathrm{P}->\mathrm{E}$} & $\mathrm{F}$ & 1.387 & 1.186 & 1.927 & 1.086 & 1.714 & 0.917 & 1.301 & 0.799 \\
\hline & p-value & 0.239 & 0.306 & 0.166 & 0.338 & 0.191 & 0.400 & 0.254 & 0.450 \\
\hline \multirow{2}{*}{$\sim \mathrm{E}->\mathrm{P}$} & $\mathrm{F}$ & 0.021 & 0.022 & 6.102 & 2.845 & 2.261 & 1.237 & 11.760 & 5.951 \\
\hline & p-value & 0.884 & 0.978 & 0.014 & 0.059 & 0.133 & 0.291 & 0.001 & 0.003 \\
\hline
\end{tabular}

F (G, P, E) - logarithmic increases in prices of wheat in France (in Germany, in Poland, contracts on the Euronext exchange); in bold black (grey) font - rejection of the null hypothesis on the lack of Granger causality for the significance level of $0.05(0.1)$.

Source: own study. 
purchased by companies in Poland were considered here, we may infer that 'adverse' events (for purchasing entities) with limited probability of their occurrence are more frequently transferred between markets. Moreover, it may be inferred that risk transfer occurs from larger wheat markets to smaller ones.

\section{CONCLUSIONS}

The results of the presented tests showed the occurrence of the effect of extreme price risk transfer on milling wheat markets in the European Union in the years 2005-2015. The wheat market in France was the market, from which risk was transferred most frequently, while markets, onto which risk was transmitted were wheat markets in Poland and in Germany. The study covered the period of drastic hikes and drops of wheat and futures contracts for wheat prices during the economic and financial crisis. The study should therefore be extended for the next years. The obtained information on the mechanism of extreme risk spillover on the EU wheat markets may be applied to provide more accurate estimations of the extreme wheat price risk.

\section{REFERENCES}

1. Cheung, Y.W., Ng, L.K. (1996). Causality-in-Variance Test and its Application to Financial Market Prices. Journal of Econometrics, 72 (1-2), pp. 33-48.

2. Christoffersen, P. (1998). Evaluating Interval Forecasts. International Economic Review, 39 (4), pp. 841-862.

3. Christoffersen, P., Pelletier, D. (2004). Backtesting Value-at-Risk: A Duration Based Approach. Journal of Financial Econometrics, 2 (1), pp. 84-108.

4. Doman, M., Doman, R. (2009). Modelowanie zmienności i ryzyka. Metody ekonometrii finansowej [Volatility and risk modelling. Methods of financial econometrics]. Oficyna, Kraków.
5. Faldziński, M. (2014). Analiza transferu ryzyka ekstremalnego między wybranymi rynkami finansowymi $\mathrm{z}$ zastosowaniem przyczynowości $\mathrm{w}$ ryzyku w sensie Grangera [Analysis of Extreme Risk Transfer across Selected Financial Markets with Application of Granger Causality in Risk]. Przegląd Statystyczny, 61 (4), pp. 433-448.

6. Granger, C.W.J. (1969). Investigating Causal Relations by Econometric Models and Cross-spectral Methods. Econometrica, 37 (3), pp. 424-438.

7. Hamulczuk, M. (2015). Powiązania przyczynowe między cenami pszenicy w Polsce i Niemczech - analiza w dziedzinie częstotliwości [Causal Links Between Wheat Prices in Poland and Germany - a Frequency Domain Approach]. Metody Ilościowe w Badaniach Ekonomicznych, 16 (3), pp. 83-92.

8. Hamulczuk, M., Łopaciuk, W. (2013). Price linkage between milling and feed wheat prices in Poland and Germany. Scientific Journal Warsaw University of Life Sciences SGGW Problems of World Agriculture, 13 (28), 4. pp. 34-44.

9. Hong, Y., Liu, Y., Wang, S. (2009). Granger Causality in Risk and Detection of Extreme Risk Spillover between Financial Markets. Journal of Econometrics, 150 (2), pp. 271-287.

10. Jajuga, K. (2007). Zarządzanie ryzykiem [Risk management]. Wydawnictwo Naukowe PWN, Warszawa.

11. Kupiec, P. (1995). Techniques for Verifying the Accuracy of Risk Management Models. Journal of Derivatives, 3, pp. 73-84.

12. McNeil, A.J., Frey, R. (2000). Estimation of Tail-Related Risk for Heteroscedastic Financial Time Series: an Extreme Value Approach. Journal of Empirical Finance, 7 (3), pp. 271-300.

13. Osińska, M. (2006). Ekonometria finansowa [Financial econometrics]. PWE, Warszawa.

14. Rembeza, J. (2009). Powiązania pomiędzy cenami produktow rolnych w Polsce i krajach UE [Linkages of agricultural commodities prices between the Polish and the EU markets]. Zeszyty Naukowe SGGW w Warszawie. Problemy Światowego Rolnictwa, 7 (22), pp. 111-119. 